\title{
KORELASI RESPON SISWA TERHADAP PENGGUNAAN MEDIA PEMBELAJARAN AUDIO VISUAL DENGAN PRESTASI BELAJAR MATA PELAJARAN MATEMATIKA POKOK BAHASAN LUAS TABUNG DI KELAS IX SMP ISLAM SURABAYA
}

\author{
Handono ${ }^{1)}$, Mohammad Taufiq ${ }^{2)}$ \\ ${ }^{1}$ PGPAUD, FKIP, Universitas Nahdlatul Ulama Surabaya \\ ${ }^{2}$ PGSD, FKIP, Universitas Nahdlatul Ulama Surabaya \\ Email: handono@unusa.ac.id
}

\begin{abstract}
Abstrak. Matematika merupakan salah satu ilmu yang memiliki peranan penting dalam upaya penguasaan IPTEK. Mengingat begitu pentingnya ilmu matematika, maka proses pembelajaran matematika pada siswa perlu mendapatkan perhatian yang khusus. Oleh karena itu guru juga harus dapat memilih metode pembelajaran yang tepat. Salah satu metode pembelajaran yang sesuai untuk memudahkan siswa dalam belajar matematika adalah dengan menggunakan media pembelajaran Audio Visual, karena media tersebut sangat menarik karena didalamnya terdapat animasi, gambar, audio, visual yang dapat membantu siswa untuk memvisualisasikan konsep matematika secara realistik. Berdasarkan uraian di atas, maka penulis mengangkat judul dalam penelitian ini sebagai berikut: Korelasi Respon Siswa Terhadap Penggunaan Media Pembelajaran Audio Visual Dengan Prestasi Belajar Mata Pelajaran Matematika Pokok Bahasan Luas Tabung Di Kelas IX SMP Islam Surabaya. Dalam penelitian ini penulis menggunakan metode penelitian kuantitatif non parametris dengan menggunakan analisa data korelasi Spearman Rank untuk pengujian Hipotesis. Populasi dari penelitian ini adalah seluruh siswa SMP Islam Surabaya, sedangkan sampel dari penelitian ini adalah semua siswa kelas IX SMP Islam Surabaya yang berjumlah 40 siswa. Adapun hasil analisa dari penelitian ini adalah semakin meningkat prosentase yang diperoleh dari hasil angket respon siswa maka semakin meningkat pula nilai prestasi belajar siswa maka dapat disimpulkan bahwa terdapat korelasi antara respon siswa terhadap penggunaan media pembelajaran Audio Visual (X) dengan prestasi belajar (Y) siswa kelas IX SMP Islam Surabaya dan dari hasil penghitungan statistik nilai korelasinya positif dan lebih besar dari $5 \%$ yaitu 0,968 maka dapat dikatakan bahwa terdapat korelasi yang signifikan.
\end{abstract}

Kata kunci: Media pembelajaran Audio Visual, Prestasi belajar 
Abstract. Mathematic is discipline that has a vital role in an effort to master of science and technology. Since the importance of mathematics, the mathematics learning process for students needs special attention. Therefore, teachers should also be able to select appropriate learning methods. One of the methods that is appropriate to help students learning math is to use Audio Visual learning media, because the media is very interesting since there are animation, images, audio, visuals involved in it. It can help students to visualize mathematical concepts in realistic. Based on the above, the authors choose the title in this study as follows: Correlation Response Students Against Use of Instructional Media Audio Visual With Subjects Mathematics Learning Achievement Highlights Size Tube In Class IX SMP Islam Surabaya. In this study the authors used quantitative research methods using the non-parametric Spearman Rank correlation data analysis for hypothesis testing. The population of this research was all Surabaya Islamic junior high school students, while samples of this study were all students of class IX SMP Islam Surabaya totaling 40 students. The result of analysis of this study was the percentage which obtained from the questionnaire responses of the students was increased.It means that the value of student achievement increasing also.It can be concluded that there was a correlation between students' response to the use of instructional media Audio Visual (X) with the learning achievement (Y) students class IX SMP Islam Surabaya and of the results were positive and the statistical correlation value is greater than $5 \%$ ie 0.968 it can be said that there is a significant correlation.

\section{Keyword: Instructional Media Audio Visual, Learning Achievement}

\section{PENDAHULUAN}

Untuk menjadikan bangsa kita menjadi bangsa yang lebih unggul, maka kiranya sangat diperlukan sumber daya manusia uang berkualitas. Sehingga dapat menghadapi perkembangan ilmu pengetahuan, teknologi dan arus globalisasiyang telah membawa perubahan di hampir semua aspek kehidupan manusia.

Dalam rangka menghadapi berbagai permasalahan yang ditimbulkannya, salah satu nya adalah melalui pendidikan yang berkualitas sehingga dapat mengaktualisasikan kompetensi pada diri siswa. Pemikiran ini kiranya selalu menjadi acuan guru untuk menyajikan pembelajaran menjadi menarik dan menyenangkan bagi siswa. Atas dasar ini maka siswa akan termotivasi untuk belajar yang pada akhirnya akan meningkatkan prestasi belajarnya.

Pada saat ini perkembangan Teknologi Informasi dan Komunikasi (TIK) telah menyentuh di segala aspek kehidupan manusia. Mulai dari dunia bisnis hingga dunia pendidikan. Sejalan dengan berkembangnya Teknologi Informasi dan Komunikasi tersebut, maka teknologi komputer tumbuh sangat pesat, sehingga keunggulan komputer tidak hanya terbatas pada kemampuan mengolah data, tetapi lebih dari itu komputer dapat menjalankan informasi yang berbasiskan komputer maka data yang masuk akan diolah secara tepat, akurat, mudah dalam mengaksesnya.

Selain sarana untuk menyajikan informasi, komputer dapat dimanfatkan di berbagai bidang misalnya pendidikan. Selain untuk dapat dimanfaatkan untuk urusan administrasi di sekolah, komputer juga memungkinkan dapat dijadikan salah satu alternatif dalam pemilihan media pembelajaran.

Penggunaan media pembelajaran merupakan salah satu kreativitas guru untuk memberikan pembelajaran menjadi lebih bermakna. Media bukan hanya berupa alat atau bahan saja, akan tetapi hal-hal lain yang memungkinkan siswa dapat memperoleh pengetahuan, keterampilan dan sikap. Jadi dalam pengetian ini, media bukan hanya alat 
perantara seperti Audio Visual, LCD projector, slide UHP.

Media Audio visual seperti VCD menurut Underwood (2000) merupakan sebuah sarana yang baik untuk membawa situasi ke dalam ruang kelas dan memanfaatkan televisi yang dewasa ini hampir dimiliki oleh semua orang. VCD ini berfungsi menyajikan tayangan gambar bergerak dan bersuara yang dapat diamati dan didengar mahasiswa. Roestiyah (1994) menyatakan bahwa media audiovisual dapat memperjelas materi yang diberikan dan dengan media dapat menyusun materi serta proses pengajaran menjadi menarik dan berhasil.

Media pembelajaran dengan menggunakan Audio Visual sangat menarik karena didalamnya terdapat animasi, gambar, audio, visual yang dapat membantu siswa untuk memvisualisasikan konsep matematika secara realistik.

Pembelajaran yang menggunakan media merupakan salah satu komponen untuk meningkatkan motivasi belajar siswa, karena dengan adanya kaitan pengetahuan yang dipelajari siswa dengan kondisi riil di masyarakat akan dapat menumbuhkan motivasi bagi siswa. Motivasi belajar siswa akan dapat mendorong siswa untuk meningkatkan prestasi belajar. Untuk dapat menumbuhkan motivasi perlu dilakukan berbagai upaya oleh guru dalam proses pembelajaran.

Dalam proses belajar, motivasi sangat diperlukan, sebab seseorang yang tidak mempunyai motivasi dalam belajar, tidak akan mungkin melakukan aktivitas dlam belajar. Oleh sebab itu, dalam belajar siswa sangat memerlukan motivasi untuk mencapai prestasi belajar yang optimal. Semakin kuat motivasi yang mendorong untuk untuk belajar semakin tinggi hasil belajar yang mungkin dicapai.

Jadi, motivasi merupakan faktor psikis yang bersifat non intelektual dimana pranannya yang khas adalah dalam hal penumbuhan gairah, rasa senang dan semangat untuk belajar. Apabila siswa memiliki motivasi yang kuat akan mempunyai banyak energi dan tekun atau ulet dalam melakukan kegiatan belajar.

\section{METODE}

Penelitian ini menggunakan metode penelitian kuantitatif non parametris dengan menggunakan analisa data korelasi Spearman Rank untuk pengujian Hipotesis. Populasi dari penelitian ini adalah seluruh siswa SMP Islam Surabaya, sedangkan sampel dari penelitian ini adalah semua siswa kelas IX SMP Islam Surabaya yang berjumlah 40 siswa.

Kerangka berpikir merupakan kerangka atau garis besar dalam pelaksanaan kegiatan penelitian. Dalam penelitian ini, peneliti mempergunakan 2 variabel independen yakni respon siswa tentang penggunaan media pembelajaran Audio Visual $(\mathrm{X})$ dan variabel terikat yakni prestasi belajar (Y). jika dikemukakan dalam bagan kerangkan berpikir dalam penelitian ini adalah sebagai berikut:

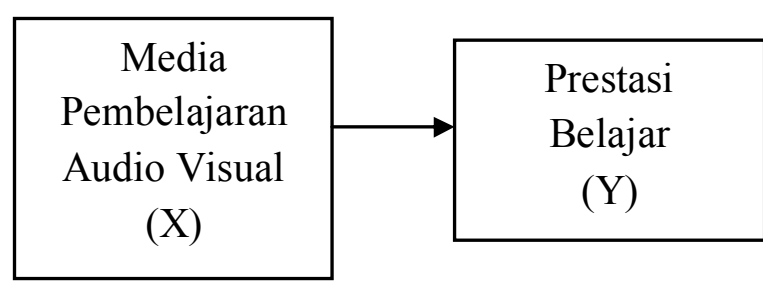

\section{Gambar 1}

\section{Alur berpikir penelitian}

Sehubungan dengan alur berpikir diatas dan proposisi-proposisi yang ada, maka dapat dirumuskan hipotesis dalam dalam penelitian sebagai berikut:

Terdapat Korelasi Antara Respon Siswa Terhadap Penggunaan Media Pembelajaran Audio Visual Dengan Prestasi Belajar Mata Pelajaran Matematika Pokok bahasan Luas Tabung Di Kelas IX SMP Islam Surabaya.

\section{HASIL DAN PEMBAHASAN}

A. Hasil Prosentase Angket Respon Siswa Dari hasil penghitungan prosentase data hasil respon siswa kelas IX SMP Islam Surabaya dari semua item 
pertanyaan pada angket koresponden dapat dideskripsikan sebagai berikut:

Tabel 1

Hasil Prosentase Respon Siswa

\begin{tabular}{|c|c|c|c|c|c|}
\hline \multirow{2}{*}{$\begin{array}{c}\text { Pertan } \\
\text { yaan }\end{array}$} & SS & S & TS & KS & $\begin{array}{c}\text { ST } \\
\text { S }\end{array}$ \\
\cline { 2 - 6 } & & & & & \\
\hline 1 & $32,5 \%$ & $37,5 \%$ & $22,5 \%$ & $7,5 \%$ & $0 \%$ \\
\hline 2 & $32,5 \%$ & $37,5 \%$ & $30 \%$ & $0 \%$ & $0 \%$ \\
\hline 3 & $65 \%$ & $5 \%$ & $22,5 \%$ & $5 \%$ & $0 \%$ \\
\hline 4 & $0 \%$ & $70 \%$ & $30 \%$ & $0 \%$ & $0 \%$ \\
\hline 5 & $45 \%$ & $25 \%$ & $22,5 \%$ & $7,5 \%$ & $0 \%$ \\
\hline 6 & $0 \%$ & $70 \%$ & $30 \%$ & $0 \%$ & $0 \%$ \\
\hline 7 & $45 \%$ & $25 \%$ & $22,5 \%$ & $7,5 \%$ & $0 \%$ \\
\hline 8 & $32,5 \%$ & $37,5 \%$ & $22,5 \%$ & $0 \%$ & $0 \%$ \\
\hline 9 & $65 \%$ & $5 \%$ & $30 \%$ & $0 \%$ & $0 \%$ \\
\hline
\end{tabular}

Pada Tabel 1. terlihat bahwa setiap item pertanyaan memiliki prosentase yang cukup bervariasi. Karena setiap opsi pilihan jawaban yang diberikan oleh peneliti menghasilkan prosentase jawaban yang berbeda-beda.

Dari data tabel 1 dapat dijabarkan sebagai berikut:

\section{Pertanyaan 1:}

Siswa menjawab SS sebesar 32,5\%, S sebesar 37,5\%, TS Sebesar 22,5\%, KS sebesar 7,5\% dan STS sebesar 0\%. Pada pertanyaan 1 nilai prosentase tertinggi adalah $37,5 \%$ dan prosentase terendah adalah $0 \%$.

\section{Pertanyaan 2:}

Siswa menjawab SS sebesar $32,5 \%$, S sebesar 37,5\%, TS Sebesar 30\%, KS sebesar $0 \%$ dan STS sebesar $0 \%$. Pada pertanyaan 2 nilai prosentase tertinggi adalah $37,5 \%$ dan prosentase terendah adalah $0 \%$.

\section{Pertanyaan 3:}

Siswa menjawab SS sebesar $65 \%$, S sebesar $5 \%$, TS Sebesar 22,5\%, KS sebesar 5\% dan STS sebesar $0 \%$. Pada pertanyaan 3 nilai prosentase tertinggi adalah $65 \%$ dan prosentase terendah adalah $0 \%$.

\section{Pertanyaan 4:}

Siswa menjawab SS sebesar $0 \%$, S sebesar $70 \%$, TS Sebesar 30\%, KS sebesar 0\% dan STS sebesar $0 \%$. Pada pertanyaan 4 nilai prosentase tertinggi adalah $70 \%$ dan prosentase terendah adalah $0 \%$.

\section{Pertanyaan 5:}

Siswa menjawab SS sebesar 45\%, S sebesar $25 \%$, TS Sebesar 22,5\%, KS sebesar 7,5\% dan STS sebesar 0\%. Pada pertanyaan 5 nilai prosentase tertinggi adalah $45 \%$ dan prosentase terendah adalah $0 \%$.

\section{Pertanyaan 6:}

Siswa menjawab SS sebesar $70 \%$, S sebesar $30 \%$, TS Sebesar 0\%, KS sebesar $0 \%$ dan STS sebesar $0 \%$. Pada pertanyaan 6 nilai prosentase tertinggi adalah $70 \%$ dan prosentase terendah adalah $0 \%$.

\section{Pertanyaan 7:}

Siswa menjawab SS sebesar $45 \%$, S sebesar $25 \%$, TS Sebesar 22,5\%, KS sebesar 7,5\% dan STS sebesar 0\%. Pada pertanyaan 7 nilai prosentase tertinggi adalah $45 \%$ dan prosentase terendah adalah $0 \%$.

\section{Pertanyaan 8:}

Siswa menjawab SS sebesar 32,5\%, S sebesar 37,5\%, TS Sebesar 22,5\%, KS sebesar 7,5\% dan STS sebesar 0\%. Pada pertanyaan 8 nilai prosentase tertinggi adalah $32,5 \%$ dan prosentase terendah adalah $0 \%$.

\section{Pertanyaan 9:}

Siswa menjawab SS sebesar $65 \%$, S sebesar $5 \%$, TS Sebesar 30\%, KS sebesar 0\% dan STS sebesar $0 \%$. Pada pertanyaan 9 nilai prosentase tertinggi adalah $65 \%$ dan prosentase terendah adalah $0 \%$.

\section{B. Deskripsi Data dan Prestasi Belajar} Siswa.

Berdasarkan data respon dan prestasi belajar siswa, dapat dideskripsikan sebagai berikut, siswa yang mendapat nilai 100 yaitu nilai tertinggi dari nilai tes prestasi siswa diantaranya adalah Dewi Rahayu dengan nilai total respon angket koresponden sebesar 42, Mahardana Wahyu S. dengan total nilai respon angket koresponden sebesar 42, Siti Aisah dengan total angket koresponden sebesar 42, Putri Rosalinda dengan nilai total angket koresponden sebesar 39, dan Desi Puspitasari dengan nilai total angket koresponden sebesar 41 .

Terdapat 3 siswa yang mendapatkan nilai 60 yaitu nilai terendah dari nilai tes prestasi siswa diantaranya adalah Eva Rosandi dengan nilai total angket koresponden sebesar 23, Aji Priyo Kuncoro dengan nilai total angket koresponden 
sebesar 26, dan Fastabiqul Choirot dengan nilai total angket korsponden sebesar 27.

Berdasarkan deskripsi data yang diperoleh semakin tinggi nilai total respon siswa terhadap media pembelajaran audio visual maka semakin tinggi pula nilai prestasi siswa. Sebaliknya semakin rendah nilai total respon siswa maka semakin rendah pula nilai prestasi siswa.

\section{Analisis Data}

Berdasarkan data rspon dan hasil belajar siswa dapat dijabarkan sebagai berikut yaitu dari hasil penghitungan $\rho_{\text {hitung }}$ diperoleh nilai sebesar 0,968 dan $\rho_{\text {tabel }}$ sebesar 0,364 , artinya $\rho_{\text {hitung }}>\rho_{\text {tabel }}$ yang berarti $\mathrm{Ha}$ diterima dan $\mathrm{H} 0$ ditolak. Ini berarti terdapat korelasi yang signifikan diantara variabel bebas (X) yakni penggunaan media pembelajaran audio visua terhadap variabel terikat $(\mathrm{Y})$ yakni prestasi belajar siswa mata pelajaran matematikadi kelas IX SMP Islam Surabaya.

\section{SIMPULAN DAN SARAN}

Berdasarkan uraian dari hasil penelitian diatas, dari data prosentase angket respon siswa dan nilai prestasi siswa maka terdapat korelasi yang signifikan yaitu antara penggunaan media pembelajaran Audio Visual (X) dengan prestasi belajar (Y) siswa mata pelajaran matematika pokok bahasa luas tabung di kelas IX SMP Islam Surabaya. Jadi, pembelajaran dengan menggunakan media Audio Visual mempunyai korelasi yang sangat baik dalam meningkatkan prestasi belajar siswa.

Saran yang penulis rekomendasikan :

1. Sebaiknya pihak sekolah dalam proses pembelajarannya menggunakan media pembelajaran Audio Visual. Karena penggunaan media pembelajaran akan dapat membantu kelancaran, efektifitas dan efisiensi pencapaian tujuan. Bahan pembelajaran dimanipulasi dalam bentuk media pembelajaran yang optimal. Media merupakan salah satu komponen yang tidak bisa diabaikan dalam sistem pembelajaran yang sukses.
2. Guru diharapkan dapat mengembangkan kreatifitas dalam pembelajaran dengan menggunakan Media Pembelajaran Audio Visual.

3. Peneliti yang lain diharapkan dapat melakukan penelitian dengan lingkup yang lebih besar.

\section{DAFTAR PUSTAKA}

Abin Syamsudin, Makmun. 2003. Pikologi Pendidikan. Bandung: Rosda Karya Remaja

Andriani, Y. (2006). Pengembangan Media Audiovisual Berbentuk VCD Dalam Upaya Peningkatan Prestasi Belajar Mahasiswa Pada Matakuliah Biofisika II Di Program Studi Fisika FMIPA Universitas Bengkulu. Bengkulu: TPSDP-P2AP UNIB.

Ardhana, W. 1990 "Media stimulasi and Types of learning". Selecting Media for Learning, Washington D.C. Association for Education Communication and technology

Arikunto, Suharsimi.2005. Prosedur Penelitian Suatu Pendekatan Praktek. Jakarta: Rineka Cipta .2002. Dasar-Dasar Evaluasi Pendidikan. Jakarta: PT. Bumi aksara

Arsyad, A.2006. Media Pembelajaran. Jakarta: PT. Raja Grafindo Persada

Djamarah, Syaiful Bahri. 2002. Psikologi Belajar.Jakarta:PT. Rineka Cipta

Dimiyati \& Mudjiono. 2002. Belajar dan Pembelajaran. Jakarta: PT. Rineka Cipta

Gagne, Atkin, M. 1986. Effective Teaching in Higher Education. Methuen: London

Gerlach, Vernon S., and Donald P. Ely, 1971, Teaching and media: Asysmatic approach, Prentice Hall, Englewood Cliffs, N.J

Hamalik, Oemar. 1994. Media Pendidikan, Bandung: PT. Citra Aditya Bhakti .1997. Metode Belajar dan Kesulitan-kesulitan Belajar. Bandung: Tarsito

Haryoko, Sapto. Efektivitas pemanfaatan media audio-visual sebagai alternatif 
optimalisasi model pembelajaran. JurnalEdukasi@Elektro 5.1 (2012). .2003. Proses Belajar Mengajar. Jakarta: PT. Bumi Aksara

Sugiyono, 2008. Statistik Non Parametris. Bandung: CV. ALFABETA

Syah, Muhibbin. 2005. Psikologi Belajar. Jakarta: PT. Raja Grafindo Persada

Underwood, Mary. 2000. Pengelolaan Kelas Yang Efektif. Terjemahan: Susi Purwoko. Jakarta : Arcan

Winatapura, Udin S. 2003. Strategi Belajar Mengajar. Jakarta: Pusat Penerbitan Universitas Terbuka

Wina Sanjaya. 2008. Strategi Pembelajaran; Berorientasi Standar Proses Pendidikan. Jakarta: Kencana Prenada Media Group. 